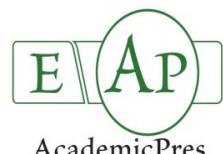

AcademicPres

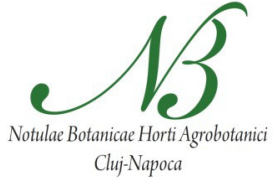

Original Article

\title{
Effects of Applications of Boron with Iron and Zinc on the Contents of Pear Trees
}

\author{
Serhat GÜREL*, Haluk BAŞAR \\ Uludă̆ University, Faculty of Agriculture, Department of Soil Science and Plant Nutrition, 16059, Görükle, Nilïfer, Bursa, \\ Turkey; sgurel@uludag.edu.tr (*correspondingauthor);bhaluk@uludag.edu.tr
}

\begin{abstract}
Boron (B) is an essential microelement for plants, animals and humans. The present study was conducted to evaluate the effectiveness of various treatments for the correction of boron $(\mathrm{B})$ with zinc $(\mathrm{Zn})$ and iron $(\mathrm{Fe})$ deficiencies in the pear cultivar 'Deveci' in the south eastern Marmara region of Turkey. This work consisted of 4 field experiments that primarly included control, soil and foliar applications of $\mathrm{B}$ alone and in combination with $\mathrm{Zn}$ and Fe. Soil and foliar applications of borax increased $B$ concentrations in leaves and fruit. However, foliar treatment with B was more effective than the soil application. Foliar applications of boron four times each season appeared to be an appropriate treatment for maintaining a sufficient $\mathrm{B}$ level in pear trees. Foliar applications of double and triple combinations of $\mathrm{FeSO}_{4} .7 \mathrm{H}_{2} \mathrm{O}$ and $\mathrm{ZnSO}_{4} .7 \mathrm{H}_{2} \mathrm{O}$ with borax significantly increased $\mathrm{Fe}$ and $\mathrm{Zn}$ concentrations in the leaves, as well. Boron concentrations were dramatically higher in the fruit parts (flesh and peel) than in the leaves. These results clearly indicated the translocation of B from soil and treated leaves to the fruits. Therefore, the $\mathrm{B}$ concentration in the fruit was more useful for the evaluation of $\mathrm{B}$ levels in pear trees.
\end{abstract}

Keywords: application, fruit, leaf, pear, microelements, translocation

\section{Introduction}

Pears (Pyrus communis L.) have a very long history of cultivation in Turkey (Gerçekçioğlu et al., 2008). World pear production reached 23.5 million tonnes in 2012. Turkey is the $5^{\text {th }}$ largest producer in the world, annually producing 439.656 tonnes/year (FAO, 2014). The south eastern Marmara region of Turkey produces $25 \%$ of the total pear crops of Turkey (TUIK, 2014). The pear has economic and traditional importance among the crops grown in this region, which has the highest production value of pears in Turkey. Pear production in Turkey and in the Marmara region has been increasing each year with such cultivars as 'Deveci', 'Santa Maria' and 'Williams' (Öztürk, 2014).

Boron is assimilated by plants from the soil and passes through the human body via the food chain (Nielsen, 1997). Boron effects the function and composition of body systems such as brain, skeleton, and the immune system as well as energy metabolism (Velioğlu and Şimşek, 2003). Boron is an essential element for plants. It has significant roles in different metabolic functions that may impact tree yield and fruit quality (Marschner, 1995). The pear is considered to be a crop with a high requirement for B (Wojcik, 2003). If boron is not present in a sufficient amount, the flowers will die before the full bloom period. Consequently, the pear fruit are set, and the yield will be reduced (Sánchez, 2005).
Boron deficiency is one of the most common worldwide plant microelement deficiencies (Shorrocks, 1997; Freeman et al., 2005; Rodrigues, 2012). Boron deficiency affects vegetative growth and reproductive processes, depending on the time and extent of the deficiency occurrence (Stellacci $e t$ al., 2010). Boron deficiency can be readily prevented and corrected by both soil and foliar applications (Ganie et al., 2013). A spray application of $\mathrm{B}$ to the leaves is more effective and economical in comparison with a soil application (Perica et al., 2002; Wojcik and Wojcik, 2003; Hudina and Stampar, 2005; Yehia and Hassan, 2005). Foliar fertilization can influence nutritive competition between different metabolic sinks and control the growth and reproductive activities of fruit trees (Wojcik, 2004).

Microelements such as $\mathrm{Fe}, \mathrm{Zn}$ and $\mathrm{B}$ are essential for different biological functions that may be responsible for tree yield and fruit quality (Shoeib, 2003; Asaad, 2014). Boron, Fe and Zn in pear groves are possibly the most important determinant elements for pears grown in calcareous or alkaline soils in the Mediterranean climate zone of Turkey (Başar, 2003; ÁlvarezFernández et al. 2004). Multiple microelement deficiencies are very common in the south-eastern Marmara region (Başar et al., 2000; Başar, 2003; Turan et al., 2013). The boron, $\mathrm{Fe}$ and $\mathrm{Zn}$ sprays are successful in combined applications and increase pear tree yields (Wojcik and Wojcik 2003; Yadav et al., 2013; Mirabdulbagh, 2014). The iron and $\mathrm{Zn}$ were applied in combinations with $\mathrm{B}$ to evaluate the effectiveness of single and combined applications of B with $\mathrm{Fe}$ and $\mathrm{Zn}$. Therefore, this study was planned to provide a solution for other widespread 
126

microelement deficiencies in combination with $\mathrm{B}$. The objectives of this study were to assess the comparative suitability of foliar versus soil B applications by considering dose and application frequency, to evaluate $\mathrm{B}$ applications, alone and in combination with other microelements, in overcoming multiple microelement deficiencies, to study the response of residual $\mathrm{B}$ effects from soil applied B in the following year and to determine the most descriptive plant part for the evaluation of the $\mathrm{B}$ level status of pear trees.

\section{Materials and methods}

The study was conducted from 2011 to 2015, in the southeastern Marmara region, which is situated in northwest Turkey. The experiments were conducted individually in 4 commercial groves, including the towns of Gürsu (3) and Osmangazi (1) in Bursa, Turkey (Fig. 1). The geographical locations of the experimental sites are presented in Table 1 . The study areas were evaluated in alluvial great soil groups according to the soil map of the Bursa province (Anonymous, 1995). The results of the soil chemical analysis are presented in Table 1 . The experiments were set up in very uniform orchards with cv. 'Deveci' pear trees, the main cultivar in the region. Twenty-one healthy; uniform and regular pear bearing trees in the each grove were used in the experiments. The trees were treated with nearly the same fertilizer program and irrigation scheduling, with adjustment for tree size. The experiments were conducted in a completely randomized design with three replications. A minimum of two or three trees were placed between the experimental trees to prevent interaction of the applications during the spraying of the compounds. Each time the spray treatments were applied with an engine sprayer, until the complete moistening of the upper and lower leaf epidermis was achieved. The treatments were applied just before night fall.

For the treatment of foliar nutrition, the trees were sprayed with boron $\left(\mathrm{Na}_{2} \mathrm{~B}_{4} \mathrm{O}_{7} \cdot 10 \mathrm{H}_{2} \mathrm{O}\right)$, zinc $\left(\mathrm{ZnSO}_{4} \cdot 7 \mathrm{H}_{2} \mathrm{O}\right)$ and iron ( $\left.\mathrm{FeSO}_{4.7} \mathrm{H} 2 \mathrm{O}\right)$. The experiments including the different $\mathrm{B}$ treatments were set up separately in 4 pear groves. Boron was applied alone and in combinations with $\mathrm{Zn}$ and Fe. For this purpose, a survey study was performed to individually evaluate the most appropriate pear grove for the experiments. The experiments were as follows: experiment I: borax single, experiment II: borax $+\mathrm{Zn}$ sulfate, experiment III: borax $+\mathrm{Fe}$ sulfate and experiment IV: borax $+\mathrm{Zn}$ sulfate + Fe sulfate deficiencies. The rest of the nutrients in the trees were adequate according to the sufficiency ranges indicated for pear trees.

The soil and foliar treatments were separately applied to the nutrient deficient trees to estimate the most effective application method for pears. The treatments mainly consisted of control, soil and foliar applications in each grove. In soil applications, 2 doses of compound(s) containing the deficient nutrient were only applied in the early spring of the first year of the experiment to estimate the residual effect in the following year. Foliar applications were sprayed onto the leaves twice and four times at two rates in the consecutive years. Treatments and application rates for each experiment are presented in Table 2.

In each orchard, the soil samples from $0-30 \mathrm{~cm}$ and $30-60 \mathrm{~cm}$ deep were collected to form a compound sample (Kacar, 2009) in the dormancy period of the trees in winter, and prepared for subsequent analyses (Chapman and Pratt, 1961). The leaf samples that were expanded to full size and had petioles were taken from the mid-part of annual shoots located on different sides of the middle section of the canopy in each grove (Kacar and Inal, 2008), after the foliar applied nutrients were assimilated by the leaves in July. The fruit samples were collected at maturity in September. After collection, leaf and fruit samples were immediately transported to the laboratory in closed polyethylene bags and washed thoroughly with tap water, acidified (0.1 M $\mathrm{HCl}$ ) water and then distilled water (Wallinga et al., 1989). Analyses were also conducted on the fruit flesh and peel. Pear fruit peels were removed by a stainless steel knife before they were dried in an oven. The fruit and leaf samples were oven-dried at $65^{\circ} \mathrm{C}$ for $72 \mathrm{~h}$ and finely ground in a stainless steel mill to pass through a $0.5 \mathrm{~mm}$ sieve. Care was taken to prevent contamination at all steps in the process.

Soil pH was measured in a 1:2.5 soil-to-water ratio. Electrical conductivity was measured in saturation extracts of soils using an EC meter. Particle size analysis was determined using a hydrometer method (Bouyoucus, 1955) and the soils were identified using the U.S. Department of Agriculture soil taxonomy (USDA, 2013). Soil organic carbon was determined by the wet oxidation method of Walkley and Black (1934). Exchangeable cations ( $\mathrm{Ca}, \mathrm{Mg}$, and $\mathrm{K}$ ) were determined after extraction with $1 M \mathrm{NH}_{4} \mathrm{OAc}$ at $\mathrm{pH} 7.0$ (Kacar, 2009). The extracts were analyzed for $\mathrm{Ca}, \mathrm{Mg}$, and $\mathrm{K}$ by a flame photometer. Available phosphorus was extracted by $\mathrm{NaHCO}_{3}$ (Olsen and Dean, 1965) and the concentration was measured colorimetrically after developing the blue color with ascorbic acid as described by Kacar and Kovanc1 (1982). The available Fe, Mn, $\mathrm{Zn}$ and $\mathrm{Cu}$, contents of the soils were extracted with $0.005 \mathrm{M}$ DTPA (Lindsay and Norvell, 1978). Available B was assayed according to Wolf(1971).

The dried plant (leaf, fruit flesh and fruit peel) samples were digested with $8 \mathrm{ml} \mathrm{HNO}_{3}(65 \%)$ and $2 \mathrm{ml} \mathrm{H}_{2} \mathrm{O}_{2}$ (30\%) in closed pressurized vessels in a microwave oven according to U.S. Environmental Protection Agency (EPA, 1994). To dissolve the dried plant samples for total elemental analysis, microwave-assisted acid decomposition was performed at high pressure and

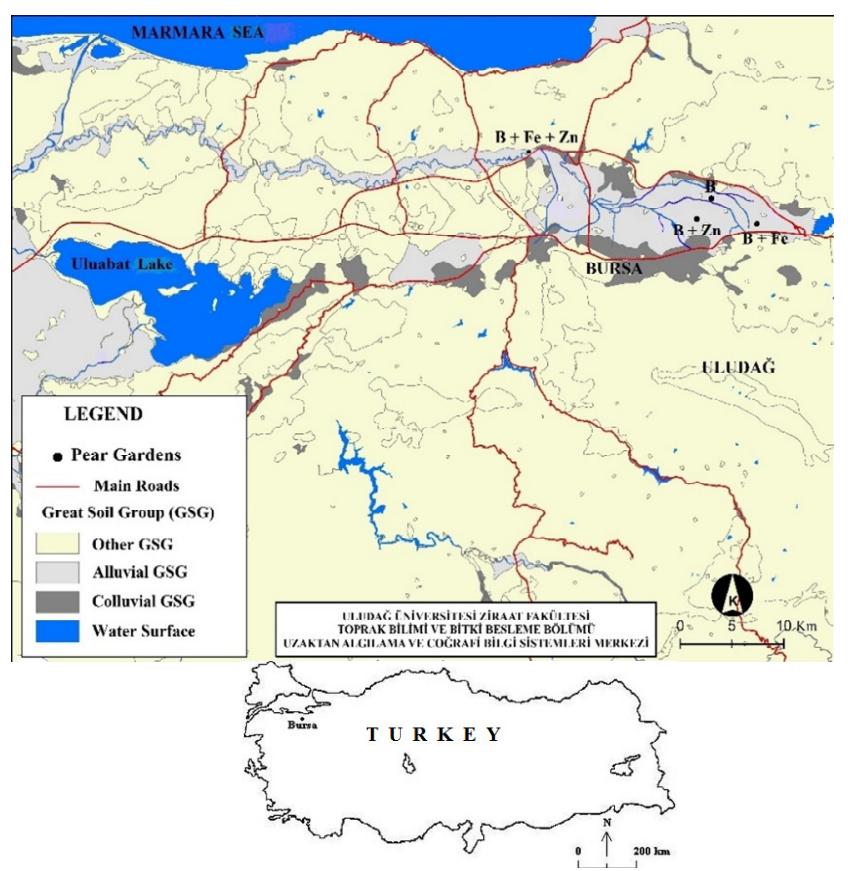

Fig. 1. The location of experimental groves in the map 
Table 1. Selected soil characteristics of the experiments

\begin{tabular}{|c|c|c|c|c|c|c|c|c|c|c|c|c|c|c|c|c|c|c|c|c|c|c|}
\hline \multirow{2}{*}{ 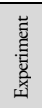 } & \multirow{2}{*}{ 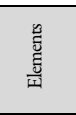 } & \multirow{2}{*}{$\begin{array}{l}\text { Soil layer } \\
(\mathrm{am})\end{array}$} & \multirow{2}{*}{$\begin{array}{l}\mathrm{P} \\
\mathrm{H}\end{array}$} & \multirow{2}{*}{$\begin{array}{c}\mathrm{EC} \\
\mu \mathrm{S} \mathrm{cm}^{-1}\end{array}$} & \multirow{2}{*}{$\begin{array}{l}\mathrm{CaCO}_{3} \\
\%\end{array}$} & \multirow{2}{*}{$\begin{array}{l}\text { O.M } \\
\%\end{array}$} & \multicolumn{3}{|c|}{ Particle size, $\%$} & \multirow{2}{*}{$\begin{array}{l}\text { Total } \\
\mathrm{N}, \\
\%\end{array}$} & \multirow{2}{*}{$\begin{array}{c}\text { Available } \\
\text { P, } \\
\mathrm{mgkg}^{-1}\end{array}$} & \multicolumn{3}{|c|}{$\begin{array}{l}\text { Extractable cations } \\
\left(\mathrm{mgkg}^{-1}\right)\end{array}$} & \multicolumn{5}{|c|}{$\begin{array}{l}\text { Available micro nutrients, } \\
\left(\mathrm{mgkg}^{-1}\right)\end{array}$} & \multicolumn{2}{|c|}{ Geographical location } & \multirow{2}{*}{$\begin{array}{r}\text { Great soil } \\
\text { group }\end{array}$} \\
\hline & & & & & & & s & $\mathrm{Si}$ & $\mathrm{C}$ & & & K & $\mathrm{Ca}$ & $\mathrm{Mg}$ & $\mathrm{Fe}$ & $\mathrm{Zn}$ & $\mathrm{Mn}$ & $\mathrm{Cu}$ & B & $\begin{array}{c}\mathrm{X} \\
\text { coordinates }\end{array}$ & $\begin{array}{c}\mathrm{Y} \\
\text { coordinates }\end{array}$ & \\
\hline \multirow[b]{2}{*}{1} & \multirow[b]{2}{*}{ B } & $0-30$ & 8.03 & 211 & 6.53 & 3.03 & 40.62 & 36.98 & 22.40 & 0.13 & 59.80 & 192 & 3617 & 209.00 & 6.53 & 1.25 & 6.29 & 7.60 & 0.78 & \multirow{2}{*}{684268} & \multirow{2}{*}{4458002} & \multirow{2}{*}{ Alluvial } \\
\hline & & $30-60$ & 8.45 & 165 & 8.07 & 0.91 & 52.33 & 30.55 & 17.12 & 0.06 & 5.80 & 104 & 3555 & 259.50 & 4.63 & 0.29 & 4.60 & 3.18 & 0.61 & & & \\
\hline \multirow[b]{2}{*}{2} & \multirow{2}{*}{$B+Z n$} & $0-30$ & 7.57 & 159 & 5.76 & 2.00 & 59.11 & 29.41 & 11.49 & 1.11 & 34.80 & 124 & 2498 & 148.40 & 5.87 & 1.42 & 9.49 & 10.30 & 0.72 & \multirow{2}{*}{684798} & \multirow{2}{*}{4457929} & \multirow{2}{*}{ Alluvial } \\
\hline & & $30-60$ & 8.09 & 75 & 5.57 & 1.48 & 86.68 & 7.73 & 5.59 & 0.02 & 12.00 & 32 & 1979 & 97.97 & 4.23 & 0.43 & 4.46 & 2.06 & 0.31 & & & \\
\hline \multirow[b]{2}{*}{3} & \multirow{2}{*}{$\mathrm{B}+\mathrm{Fe}$} & $0-30$ & 8.03 & 164 & 5.38 & 2.22 & 55.39 & 28.71 & 15.89 & 0.08 & 31.80 & 231 & 3222 & 168.60 & 11.94 & 0.69 & 7.02 & 19.48 & 0.74 & \multirow[b]{2}{*}{68868} & \multirow[b]{2}{*}{4454895} & \multirow[b]{2}{*}{ Alluvial } \\
\hline & & $30-60$ & 8.45 & 152 & 8.84 & 1.70 & 53.27 & 24.71 & 14.13 & 0.04 & 4.00 & 53 & 4116 & 259.50 & 4.00 & 0.15 & 6.76 & 2.56 & 0.34 & & & \\
\hline \multirow{2}{*}{4} & \multirow{2}{*}{$\mathrm{B}+\mathrm{Zn}+\mathrm{Fe}$} & $0-30$ & 7.64 & 171 & 6.53 & 3.11 & 70.39 & 8.01 & 21.60 & 0.10 & 13.80 & 358 & 3453 & 501.90 & 3.79 & 0.54 & 21.12 & 6.76 & 0.62 & \multirow{2}{*}{668569} & \multirow{2}{*}{4461477} & 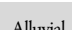 \\
\hline & & $30-60$ & 7.76 & 184 & 10.38 & 2.37 & 60.70 & 16.07 & 23.23 & 0.06 & 11.80 & 163 & 4035 & 350.40 & 2.17 & 1.04 & 10.93 & 1.44 & 0.39 & & & Alluval \\
\hline
\end{tabular}

Table 2. Treatments applied in the present experiments

\begin{tabular}{|c|c|c|c|c|c|c|c|c|c|c|}
\hline \multirow{3}{*}{ Treatments*** } & \multirow{3}{*}{$\begin{array}{l}\text { Application } \\
\text { Stage* }^{*}\end{array}$} & \multirow{3}{*}{ 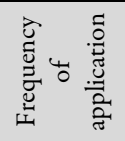 } & \multicolumn{8}{|c|}{ Rate of Compounds ${ }^{* *}$ in Experiments ${ }^{* * * *}$} \\
\hline & & & \multicolumn{2}{|c|}{ Experiment 1} & \multicolumn{2}{|c|}{ Experiment 2} & \multicolumn{2}{|c|}{ Experiment 3} & \multicolumn{2}{|c|}{ Experiment 4} \\
\hline & & & B & B & $\mathrm{ZnS}$ & B & $\mathrm{FeS}$ & B & $\mathrm{ZnS}$ & $\mathrm{FeS}$ \\
\hline Control & - & 0 & 0 & 0 & 0 & 0 & 0 & 0 & 0 & 0 \\
\hline Soil 1 & Early spring & 1 & 250 & 250 & 250 & 250 & 500 & 250 & 250 & 500 \\
\hline Soil 2 & Early spring & 1 & 500 & 500 & 500 & 500 & 1000 & 500 & 500 & 1000 \\
\hline Foliar 1 & $1^{\text {st }}, 2^{\text {nd }}$ & 2 & $0.25 \%$ & $0.25 \%$ & $0.10 \%$ & $0.25 \%$ & $0.10 \%$ & $0.25 \%$ & $0.10 \%$ & $0.10 \%$ \\
\hline Foliar 2 & $1^{\text {st }}, 2^{\text {nd }}, 3^{\text {rd }}, 4^{\text {th }}$ & 4 & $0.25 \%$ & $0.25 \%$ & $0.10 \%$ & $0.25 \%$ & $0.10 \%$ & $0.25 \%$ & $0.10 \%$ & $0.10 \%$ \\
\hline Foliar 3 & $1^{\text {st }}, 2^{\text {nd }}$ & 2 & $0.50 \%$ & $0.50 \%$ & $0.20 \%$ & $0.50 \%$ & $0.20 \%$ & $0.50 \%$ & $0.20 \%$ & $0.20 \%$ \\
\hline Foliar 4 & $1^{\text {st }}, 2^{\text {nd }}, 3^{\text {rd }}, 4^{\text {th }}$ & 4 & $0.50 \%$ & $0.50 \%$ & $0.20 \%$ & $0.50 \%$ & $0.20 \%$ & $0.50 \%$ & $0.20 \%$ & $0.20 \%$ \\
\hline
\end{tabular}

${ }^{*}$ Application stage: 1 st : 3 weeks after full bloom.

2nd: 5 weeks after full bloom.
3rd: 7 weeks after full bloom.

4th: 9 weeks after full bloom.

** Compounds: B: Borax (sodium tetra borate decahydrate; Na2B4O7.10H2O), 12 B \%

$\mathrm{ZnS}$ : Zinc sulphate heptahydrate; ZnSO4.7H2O, $22 \mathrm{Zn} \%$

$\mathrm{FeS}$ : Iron sulphate heptahydrate; FeSO $4.7 \mathrm{H} 2 \mathrm{O}, 17 \mathrm{Fe} \%$

***Treatments:

Soil treatments: $g$ tree- 1

Foliar treatments: $30 \mathrm{ml}$ of glutechin (alkyl-poliglucoside) as surfactant was added to 1001 of spray solution.

****Experiments: The experiment was consisted of 7 treatments with 3 replications.

temperature (Model Start D, Milestone S.r.l, Sorisole, Italy). The iron and zinc contents in the digest were analyzed with an atomic absorption spectrometer (Model A Analist 400, Perkin Elmer, Waltham, Massachusetts, USA). Leaf and fruit B concentrations were determined colorimetrically using the Azomethin- $\mathrm{H}$ method after dry combustion (Kacar and Inal, 2008).

All of the analyses were carried out in duplicate and the results were subjected to statistical analysis. Simple correlations were made among the data, which were obtained from the soil, leaf and fruit (flesh and peel) samples (SAS, 2005).

Selected chemical and physical properties of the soils and the concentrations of some elements in the soils are given in Table 2 .

\section{Results and Discussion}

Experiment I. Effects of soil and foliar applied B on B concentrations in the leaves and in the fruit

Soil and foliar applications of $B$ in the form of borax increased the $\mathrm{B}$ concentrations in both plant parts compared with the control (Table 3). However, the leaf B concentration was not statistically significantly influenced. Nevertheless, the treatments resulted in dramatically higher $\mathrm{B}$ concentrations in the fruits than in the leaves. In fact the B content in the fruit was significantly influenced by the soil and foliar applications in each year of the experiment.

The results showed that the soil application of borax at the rate of $500 \mathrm{~g}$ per tree was the most effective soil treatment compared with the control and the $250 \mathrm{~g}$ tree $^{-1}$ treatments. In contrast, the results of LSD (Least Significant Difference) test also showed that the 4 application of borax 4 times at the rate of $0.5 \%$ was the most effective treatment to increase $\mathrm{B}$ concentrations in the fruit. The existence of the highest $\mathrm{B}$ concentrations in the fruit samples indicated that the majority of $\mathrm{B}$ absorbed by the roots and the leaves were transferred to and accumulated in the fruit. However, the effect of the soil-applied B was more evident on the fruit, especially on the fruit flesh. The fruit B concentration decreased in the first year of the experiment. The reason might be that $\mathrm{B}$ was not applied into soil in the second year of the experiment to observe if a residual effect of the soil-applied B existed. Wojcik (2003) indicates that pre-bloom and post harvest B sprays are successful in increasing pear tree yield and improving fruit storability under low B availability conditions in the soil.

Experiment II. Effect of combined soil and foliar application of $B$ and $Z n$ on the $B$ and $Z n$ concentrations in the leaves and the fruit

Soil and foliar-applied borax increased the leaf B contents in both years of the experiment (Table 4). The highest B concentration in the leaves was obtained with the application of $\mathrm{B}$ in combination with $\mathrm{Zn}$ compared with the other 3 foliar treatment experiments. With soil and foliar applications, the B concentrations in the fruit samples were dramatically and statistically higher than for the control treatment in the first year of the experiment. The highest $\mathrm{B}$ concentration was obtained with the treatment of foliar application of borax 4 times at a rate of 
Table 3. Effects of soil and foliar applied B on B concentrations in leaves and fruits (flesh and peel)

\begin{tabular}{|c|c|c|c|c|c|c|c|}
\hline \multirow{3}{*}{ B } & & \multicolumn{6}{|c|}{$\mathrm{mg} \mathrm{kg}^{-1}$} \\
\hline & & \multicolumn{2}{|c|}{ Leaf } & \multicolumn{2}{|c|}{ Fruit Flesh } & \multicolumn{2}{|c|}{ Fruit Peel } \\
\hline & & Year 1 & Year 2 & Year 1 & Year 2 & Year 1 & Year 2 \\
\hline Control & 0 & 21.47 & 21.44 & $18.41 \mathrm{c}$ & $19.58 \mathrm{c}$ & $18.53 \mathrm{c}$ & $13.99 \mathrm{c}$ \\
\hline Soil $1\left(250 \mathrm{~g}\right.$ borax tree $\left.{ }^{-1}\right)$ & 1 & 25.92 & 21.45 & $18.03 \mathrm{c}$ & $18.82 \mathrm{c}$ & $26.97 \mathrm{bc}$ & $11.70 \mathrm{c}$ \\
\hline Soil 2 (500 g borax tree $\left.{ }^{-1}\right)$ & 1 & 30.36 & 21.62 & $42.84 \mathrm{ab}$ & $28.23 c$ & $30.05 \mathrm{~b}$ & $20.00 \mathrm{bc}$ \\
\hline Foliar 1 (Spraying $0.25 \%$ borax) & 2 & 24.51 & 24.84 & $21.16 \mathrm{c}$ & $25.35 c$ & $22.19 \mathrm{c}$ & $19.58 \mathrm{bc}$ \\
\hline Foliar 2 (Spraying $0.25 \%$ borax) & 4 & 29.06 & 24.84 & $37.63 \mathrm{~b}$ & $49.08 \mathrm{ab}$ & $35.17 \mathrm{~b}$ & $31.79 \mathrm{a}$ \\
\hline Foliar 3 (Spraying $0.50 \%$ borax) & 2 & 23.97 & 21.53 & $44.92 \mathrm{ab}$ & $45.60 \mathrm{~b}$ & $25.70 \mathrm{bc}$ & $28.82 \mathrm{ab}$ \\
\hline Foliar 4 (Spraying $0.50 \%$ borax $)$ & 4 & 28.74 & 26.79 & $64.04 a$ & $62.39 \mathrm{a}$ & $64.23 \mathrm{a}$ & $34.92 \mathrm{a}$ \\
\hline $\mathrm{F}$ & & NS & NS & ${ }^{* *}$ & ** & ** & ** \\
\hline $\operatorname{LSD}(0.05)$ & & & & 23.29 & 14.72 & 17.41 & 10.12 \\
\hline
\end{tabular}

Table 4. Effects of soil and foliar applied B and $\mathrm{Zn}$ on B and $\mathrm{Zn}$ concentrations in leaves and fruit samples

\begin{tabular}{|c|c|c|c|c|c|c|c|}
\hline \multirow{3}{*}{ B } & & \multicolumn{6}{|c|}{$\mathrm{mg} \mathrm{kg}^{-1}$} \\
\hline & & \multicolumn{2}{|c|}{ Leaf } & \multicolumn{2}{|c|}{ Fruit Flesh } & \multicolumn{2}{|c|}{ Fruit Peel } \\
\hline & & Year 1 & Year 2 & Year 1 & Year 2 & Year 1 & Year 2 \\
\hline Control & 0 & $20.82 \mathrm{~d}$ & 28.48 & 21.36 & $13.06 \mathrm{c}$ & $18.13 \mathrm{~d}$ & $15.09 \mathrm{c}$ \\
\hline Soil 1 (250 g borax tree $\left.{ }^{-1}\right)$ & 1 & $24.51 \mathrm{~cd}$ & 31.87 & 19.85 & $13.05 \mathrm{c}$ & $20.39 \mathrm{~d}$ & $17.72 \mathrm{c}$ \\
\hline Soil 2 (500 g borax tree $\left.{ }^{-1}\right)$ & 1 & $27.33 \mathrm{bc}$ & 27.04 & 45.55 & $23.82 \mathrm{bc}$ & $21.65 \mathrm{~cd}$ & $20.68 \mathrm{bc}$ \\
\hline Foliar 1 (Spraying $0.25 \%$ borax) & 2 & $29.50 \mathrm{bc}$ & 31.96 & 26.56 & $22.46 \mathrm{c}$ & $19.40 \mathrm{~d}$ & $19.24 \mathrm{c}$ \\
\hline Foliar 2 (Spraying $0.25 \%$ borax) & 4 & $30.47 \mathrm{~b}$ & 36.20 & 24.29 & $43.99 \mathrm{a}$ & $24.19 b c$ & $22.04 \mathrm{bc}$ \\
\hline Foliar 3 (Spraying $0.50 \%$ borax) & 2 & $31.45 \mathrm{~b}$ & 25.01 & 36.76 & $35.69 \mathrm{ab}$ & $25.75 \mathrm{~b}$ & $30.09 \mathrm{~b}$ \\
\hline Foliar 4 (Spraying $0.50 \%$ borax $)$ & 4 & $39.58 \mathrm{a}$ & 35.26 & 41.53 & $45.86 \mathrm{a}$ & $43.59 \mathrm{a}$ & $41.62 \mathrm{a}$ \\
\hline F & & * & NS & NS & * & ** & ** \\
\hline \multicolumn{2}{|l|}{$\operatorname{LSD}(0.05)$} & 5.97 & & & 12.85 & 17.41 & 10.48 \\
\hline \multirow{2}{*}{$\mathrm{Zn}$} & & \multicolumn{2}{|c|}{ Leaf } & \multicolumn{2}{|c|}{ Fruit Flesh } & \multicolumn{2}{|c|}{ Fruit Peel } \\
\hline & & Year 1 & Year 2 & Year 1 & Year 2 & Year 1 & Year 2 \\
\hline Control & 0 & $37.83 \mathrm{~b}$ & $28.14 \mathrm{~d}$ & $5.70 b c$ & 4.73 & 10.53 & 7.80 \\
\hline Soil $1\left(250 \mathrm{~g} \mathrm{ZnSO}_{4} .7 \mathrm{H}_{2} \mathrm{O}\right.$ tree $\left.^{-1}\right)$ & 1 & $42.35 \mathrm{~b}$ & $25.34 \mathrm{~d}$ & $4.89 c$ & 5.98 & 7.16 & 6.24 \\
\hline Soil $2\left(500 \mathrm{~g} \mathrm{ZnSO}_{4} .7 \mathrm{H}_{2} \mathrm{O}\right.$ tree $\left.^{-1}\right)$ & 1 & $42.75 \mathrm{~b}$ & $27.51 \mathrm{~d}$ & $4.76 \mathrm{c}$ & 4.14 & 8.23 & 6.57 \\
\hline 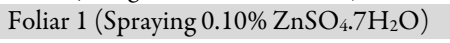 & 2 & $92.38 \mathrm{ab}$ & $94.22 \mathrm{c}$ & $7.03 \mathrm{ab}$ & 5.44 & 11.30 & 10.42 \\
\hline Foliar 2 (Spraying $0.10 \% \mathrm{ZnSO}_{\left.4.7 \mathrm{H}_{2} \mathrm{O}\right)}$ & 4 & $90.40 \mathrm{ab}$ & $136.40 \mathrm{~b}$ & $6.19 \mathrm{abc}$ & 5.04 & 10.36 & 5.44 \\
\hline Foliar 3 (Spraying $0.20 \% \mathrm{ZnSO}_{4} .7 \mathrm{H}_{2} \mathrm{O}$ ) & 2 & $131.14 \mathrm{a}$ & $101.80 \mathrm{c}$ & $6.75 \mathrm{ab}$ & 6.30 & 10.93 & 7.74 \\
\hline 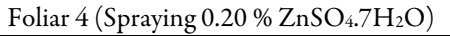 & 4 & $157.16 \mathrm{a}$ & $239.26 \mathrm{a}$ & $7.89 \mathrm{a}$ & 3.80 & 16.53 & 10.17 \\
\hline F & & ${ }^{*}$ & ** & * & NS & NS & NS \\
\hline $\operatorname{LSD}(0.05)$ & & 75. & & 26.70 & & & \\
\hline
\end{tabular}

$0.5 \%$. In addition, the residual effect of soil-applied B in the fruit flesh samples at the rate of $500 \mathrm{~g}$ tree ${ }^{-1}$ was more evident. These results are also consistent with the results of experiment $\mathrm{I}$, in which the fruits contained more $B$ than the leaves and verify the translocation of $\mathrm{B}$ into the tree.

The combined application of $\mathrm{B}$ and $\mathrm{Zn}$-containing compounds did not exhibit contrary trends to the single application of B. Regarding $\mathrm{Zn}$ treatments, the foliar application of $\mathrm{Zn}$ increased $\mathrm{Zn}$ contents in the leaves and the fruit. However, these increases were not statistically significant in the fruits. In contrast to the partitioning of $\mathrm{B}$ between the leaves and the fruits, the $\mathrm{Zn}$ concentration in fruit was lower than in the leaves. Additionally in contrast to the partitioning of $B$ between the fruit flesh and the fruit peel, the $\mathrm{Zn}$ concentration in the fruit flesh was lower than in the fruit peel. This different behavior of $\mathrm{B}$ and $\mathrm{Zn}$ could be attributed to the poor mobility of foliar-applied $\mathrm{Zn}$ in the tree (Ferrandon and Chamel, 1988; Zhang and Brown, 1999). The results of the $B+Z n$ experiment also indicated that there was no adverse relationship between $\mathrm{B}$ and $\mathrm{Zn}$ in absorbtion by the roots and the leaves. Therefore, when $B$ and $Z n$ deficiencies occur at the same time, this problem could be handled by the application of those compounds together in pear trees. Taheri and Talaie (2001) indicated that a B and Zn spray had a significant effect on the concentration of these elements in the leaves and fruits of olive trees. The application of foliar $\mathrm{Zn}$ and $\mathrm{B}$ significantly promoted the qualitative and quantitative characteristics of pear trees (Canesin and Buzetti, 2007; Canesin et al., 2010). The combined foliar application of $\mathrm{B}$ and $\mathrm{Zn}$ maximizes the yield and extends the bearing life of citrus fruit plants, while significantly reducing the dieback, chlorosis and rosette tree in citrus plants (Sajid et al., 2010).

\section{Experiment III. Effect of combined soil and foliar application of B and Fe on the B and Fe concentrations in the leaves and the fruit}

The results of the amount of $B$ detected in the fruit flesh and fruit peel samples changed meaningfully in relation to the treatments (Table 5). The effects of the treatments were observed more clearly in the second year of the experiment than in the first year in almost each treatment. Although the soil application of borax was performed only in the first year of the experiment, the highest concentrations were observed in the fruit flesh and peel samples of the second year. Similar to the other 3 experiments, the B contents of the fruit samples were clearly higher than that of the leaf samples. The most effective foliar rate of borax for increasing the $\mathrm{B}$ content of different plant parts appeared to be 4 times at a $0.5 \%$ concentration. 
Table 5. Effects of soil and foliar applied B and Fe on B and Fe concentrations in leaves and fruit samples

\begin{tabular}{|c|c|c|c|c|c|c|c|}
\hline \multirow{3}{*}{ B } & & \multicolumn{6}{|c|}{$\mathrm{mg} \mathrm{kg}^{-1}$} \\
\hline & & \multicolumn{2}{|c|}{ Leaf } & \multicolumn{2}{|c|}{ Fruit Flesh } & \multicolumn{2}{|c|}{ Fruit Peel } \\
\hline & & Year 1 & Year 2 & Year 1 & Year 2 & Year 1 & Year 2 \\
\hline Control & 0 & 14.53 & 20.09 & $4.12 \mathrm{c}$ & $9.75 \mathrm{~d}$ & $9.91 \mathrm{c}$ & $11.95 \mathrm{c}$ \\
\hline Soil $1\left(250 \mathrm{~g}\right.$ borax tree $\left.{ }^{-1}\right)$ & 1 & 19.63 & 24.33 & $12.94 \mathrm{c}$ & $17.72 \mathrm{~cd}$ & $11.05 \mathrm{c}$ & $16.44 \mathrm{bc}$ \\
\hline Soil 2 (500 $\mathrm{g}_{\text {borax }}$ tree $\left.^{-1}\right)$ & 1 & 18.22 & 29.16 & $18.60 \mathrm{bc}$ & $28.99 \mathrm{bc}$ & $20.78 \mathrm{~b}$ & $19.16 \mathrm{bc}$ \\
\hline Foliar 1 (Spraying $0.25 \%$ borax) & 2 & 17.56 & 25.60 & $16.25 b c$ & $24.07 \mathrm{bc}$ & $17.20 \mathrm{bc}$ & $25.68 \mathrm{bc}$ \\
\hline Foliar 2 (Spraying $0.25 \%$ borax) & 4 & 19.74 & 29.33 & $25.04 \mathrm{~b}$ & $24.58 \mathrm{bc}$ & $22.10 \mathrm{~b}$ & $27.29 b$ \\
\hline Foliar 3 (Spraying $0.50 \%$ borax) & 2 & 20.27 & 28.91 & $26.27 b$ & $33.48 b$ & $22.95 \mathrm{~b}$ & $42.04 a$ \\
\hline Foliar 4 (Spraying $0.50 \%$ borax) & 4 & 20.05 & 27.38 & $53.34 a$ & $51.62 \mathrm{a}$ & $40.85 a$ & $49.84 \mathrm{a}$ \\
\hline $\mathrm{F}$ & & NS & NS & * & ** & ** & * \\
\hline $\operatorname{LSD}(0.05)$ & & & & 20.15 & 12.10 & 13.32 & 14.37 \\
\hline \multirow{2}{*}{$\mathrm{Fe}$} & & \multicolumn{2}{|c|}{ Leaf } & \multicolumn{2}{|c|}{ Fruit Flesh } & \multicolumn{2}{|c|}{ Fruit Peel } \\
\hline & & Year 1 & Year 2 & Year 1 & Year 2 & Year 1 & Year 2 \\
\hline Control & 0 & $68.56 \mathrm{~cd}$ & $98.88 \mathrm{de}$ & $10.69 \mathrm{c}$ & 6.19 & $9.15 \mathrm{~d}$ & $23.15 \mathrm{bc}$ \\
\hline Soil $1\left(500 \mathrm{~g} \mathrm{FeSO}_{4} .7 \mathrm{H}_{2} \mathrm{O}\right.$ tree $\left.^{-1}\right)$ & 1 & $69.42 \mathrm{~cd}$ & $101.72 \mathrm{de}$ & $13.12 \mathrm{bc}$ & 7.03 & $9.54 \mathrm{~cd}$ & $14.64 \mathrm{c}$ \\
\hline Soil $2\left(1000 \mathrm{~g} \mathrm{FeSO}_{4 .} 7 \mathrm{H}_{2} \mathrm{O}\right.$ tree $\left.^{-1}\right)$ & 1 & $64.41 \mathrm{~d}$ & 98.48 e & $11.93 \mathrm{bc}$ & 5.61 & $8.50 \mathrm{~d}$ & $19.59 \mathrm{c}$ \\
\hline 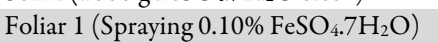 & 2 & $98.83 \mathrm{c}$ & $164.71 \mathrm{~cd}$ & $13.55 \mathrm{bc}$ & 7.40 & $10.32 \mathrm{~cd}$ & $23.34 \mathrm{bc}$ \\
\hline 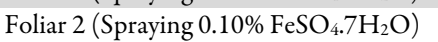 & 4 & $153.38 \mathrm{~b}$ & $240.67 \mathrm{ab}$ & $14.96 \mathrm{bc}$ & 7.37 & $15.67 \mathrm{~b}$ & $34.13 \mathrm{ab}$ \\
\hline Foliar 3 (Spraying $0.20 \% \mathrm{FeSO}_{4.7} 7 \mathrm{H}_{2} \mathrm{O}$ ) & 2 & $136.04 \mathrm{~b}$ & $182.07 \mathrm{bc}$ & $15.75 \mathrm{ab}$ & 6.87 & $14.05 \mathrm{bc}$ & $31.71 \mathrm{ab}$ \\
\hline Foliar 4 (Spraying $0.20 \% \mathrm{FeSO}_{4} .7 \mathrm{H}_{2} \mathrm{O}$ ) & 4 & $261.53 a$ & $300.50 \mathrm{a}$ & $19.72 \mathrm{a}$ & 6.20 & $22.96 \mathrm{a}$ & $42.07 \mathrm{a}$ \\
\hline $\mathrm{F}$ & & ** & ** & * & NS & ** & * \\
\hline $\operatorname{LSD}(0.05)$ & & 32.39 & 65.84 & 4.32 & & 4.87 & 10.97 \\
\hline
\end{tabular}

${ }^{*} \mathrm{p}<0.05,{ }^{* *} \mathrm{p}<0.01, \mathrm{NS}$ : not significant

The iron contents, determined in both plant parts, were considerably higher than the control and the sufficiency ranges proposed for pears in all foliar-applied trees. It is already known that, the soil application of $\mathrm{Fe}(\mathrm{II})$ sulfate does not increase the $\mathrm{Fe}$ concentrations in the plant tissues. In fact, soil-applied Fe(II) sulfate is of little or no agronomic value in calcareous soils where the $\mathrm{Fe}^{+2}$ is subjected to rapid oxidation and insolubilisation as a hydroxide (Tagliavini and Rombolá, 2001). However, the foliar application of Fe raised the Fe concentrations in the leaf samples more than the same concentrations in the fruit tissues. Therefore, the results of experiment III highlighted that the combined application of borax and iron sulfate could be readily performed in cases where $\mathrm{B}$ and $\mathrm{Fe}$ deficiencies appeared together. Jin et al. (2008) indicated that compared with the control, the contents of $\mathrm{Fe}, \mathrm{Zn}$, protein and 16 amino acids increased significantly with the application of combination of foliar $\mathrm{Fe}+$ boron complex.

\section{Experiment IV. Effect of combined soil and foliar application of B,}

$Z n$ and $F e$ on the B, $Z n$ and Fe concentrations in the leaves and the fruit

Soil and foliar applied borax combined with $\mathrm{Fe}$ and $\mathrm{Zn}$ enhanced the B concentrations in the plant samples (Table 6). There were statistically significant differences between B concentrations in the untreated trees and the soil applied trees. Soil applied borax showed higher B concentrations in the leaves and the fruit flesh samples in the second year compared with the first year. However, the fruit peel $\mathrm{B}$ concentrations decreased in the second year. In addition, the soil-applied B concentrations in the fruit flesh were slightly higher than in the fruit peel. In contrast, the soil application of $\mathrm{B}$ in combination with $\mathrm{Fe}$ and $\mathrm{Zn}$ did not have significant effects on the $\mathrm{B}$ concentrations in the fruits compared with the $\mathrm{B}+\mathrm{Zn}$ (experiment II) and $\mathrm{B}$ alone (experiment I) application experiments.

Repeated foliar applications of borax resulted in higher B concentrations in the fruit flesh compared with the leaves. These differences produced statistically meaningful relationships in both years of the experiment. Boron in the fruit of foliar-applied trees accumulated significantly compared with control and soil treatments. The findings of this two year experiment indicated that the highest $\mathrm{B}$ concentrations in the fruit were obtained with the repeated application of borax 4 times at the rate $0.5 \%$. In addition, the $\mathrm{Fe}$ and $\mathrm{Zn}$ concentrations significantly increased in only the foliar-applied leaves. The iron and zinc concentrations in the leaves and fruit did not demonstrate significantly meaningful differences with control trees by the soil application of $\mathrm{Fe}$ and $\mathrm{Zn}$-containing compounds. The iron and $\mathrm{Zn}$ contents of fruits only indicated significant increases in the 4 times repeated foliar applications. Based on the aforementioned results, pear trees are well able to take up a combination of $\mathrm{B}, \mathrm{Zn}$ and $\mathrm{Fe}$ in some solution without any hazardous effect.

The iron and zinc concentrations increased significantly in only foliar applied leaves. The iron and $\mathrm{Zn}$ concentrations in the leaves and fruit did not demonstrate statistically meaningful differences with the control trees by the soil application of $\mathrm{Fe}$ and $\mathrm{Zn}$ containing compounds. Regarding the $\mathrm{Fe}$ and $\mathrm{Zn}$ concentrations in the fruit of the foliar-treated trees, the concentrations of those 2 elements changed accordingly in relation to the treatments. For example, the Fe contents of the fruit peels and the $\mathrm{Zn}$ contents of the edible parts showed significant increases in the second year. These results are generally consistent with the other 2 experiments mentioned above. Based on the aforementioned results, the above ground parts of the pear are well able to take up the combination of $\mathrm{B}, \mathrm{Zn}$ and $\mathrm{Fe}$ in the same solution without any hazardous effect. In contrast, foliar application treatments of a $\mathrm{B}+\mathrm{Fe}+\mathrm{Zn}$ combination can produce the highest values for harvest, yield and quality (Anees $e t$ al., 2011; Abdel-Latif and El Haggan, 2014).

The $\mathrm{B}$ contents in the fruit parts and leaves were influenced by the soil and foliar applications of boron. Apparently, the fruit $\mathrm{B}$ contents evidently appeared in higher amounts than in the leaves in each experiment, as well. This could be due to translocation of the boron from the treated leaves to the developing tissues. In other words, higher B concentrations in 
Table 6. Effects of soil and foliar applied B, Zn and Fe on B, Zn and Fe concentrations in leaves and fruit samples

\begin{tabular}{|c|c|c|c|c|c|c|c|}
\hline \multirow{3}{*}{ B } & & \multicolumn{6}{|c|}{$\mathrm{mg} \mathrm{kg}^{-1}$} \\
\hline & & \multicolumn{2}{|c|}{ Leaf } & \multicolumn{2}{|c|}{ Fruit Flesh } & \multicolumn{2}{|c|}{ Fruit Peel } \\
\hline & & Year 1 & Year 2 & Year 1 & Year 2 & Year 1 & Year 2 \\
\hline Control & 0 & $19.52 \mathrm{~b}$ & 23.90 & $16.44 \mathrm{c}$ & $18.22 \mathrm{~b}$ & $15.66 \mathrm{~d}$ & 15.00 \\
\hline Soil $1\left(250 \mathrm{~g}\right.$ borax tree $\left.{ }^{-1}\right)$ & 1 & $20.61 \mathrm{~b}$ & 21.45 & $16.04 \mathrm{c}$ & $21.95 \mathrm{ab}$ & $19.83 \mathrm{~cd}$ & 18.48 \\
\hline Soil $2\left(500 \mathrm{~g}_{\text {borax }}\right.$ tree $\left.^{-1}\right)$ & 1 & $22.66 \mathrm{~b}$ & 29.58 & $21.63 \mathrm{bc}$ & $27.72 \mathrm{ab}$ & $21.73 \mathrm{bcd}$ & 20.34 \\
\hline Foliar 1 (Spraying $0.25 \%$ borax) & 2 & $19.08 \mathrm{~b}$ & 23.57 & $19.26 \mathrm{c}$ & $17.63 \mathrm{~b}$ & $19.07 \mathrm{~d}$ & 18.22 \\
\hline Foliar 2 (Spraying $0.25 \%$ borax) & 4 & $21.36 \mathrm{~b}$ & 27.38 & $28.45 \mathrm{~b}$ & $32.72 \mathrm{a}$ & $27.59 \mathrm{~b}$ & 26.36 \\
\hline Foliar 3 (Spraying $0.50 \%$ borax) & 2 & $20.49 \mathrm{~b}$ & 23.48 & $23.43 \mathrm{bc}$ & $23.14 \mathrm{ab}$ & $25.32 \mathrm{bc}$ & 17.89 \\
\hline Foliar 4 (Spraying $0.50 \%$ borax $)$ & 4 & $28.52 \mathrm{a}$ & 26.53 & $52.30 \mathrm{a}$ & $33.06 \mathrm{a}$ & $47.95 \mathrm{a}$ & 25.43 \\
\hline $\mathrm{F}$ & & * & NS & ** & * & ** & NS \\
\hline $\operatorname{LSD}(0.05)$ & & 5.65 & & 8.72 & 11.28 & 6.08 & \\
\hline \multirow{2}{*}{$\mathrm{Zn}$} & & \multicolumn{2}{|c|}{ Leaf } & \multicolumn{2}{|c|}{ Fruit Flesh } & \multicolumn{2}{|c|}{ Fruit Peel } \\
\hline & & Year 1 & Year 2 & Year 1 & Year 2 & Year 1 & Year 2 \\
\hline Control & 0 & $24.69 \mathrm{c}$ & $22.43 \mathrm{~d}$ & $2.83 \mathrm{~b}$ & 3.85 & $5.80 \mathrm{~d}$ & $5.78 \mathrm{bc}$ \\
\hline Soil $1\left(250 \mathrm{~g} \mathrm{ZnSO}_{4} .7 \mathrm{H}_{2} \mathrm{O}\right.$ tree $\left.^{-1}\right)$ & 1 & $23.41 \mathrm{c}$ & $21.43 \mathrm{~d}$ & $3.49 \mathrm{~b}$ & 3.32 & $5.40 \mathrm{~d}$ & $4.07 \mathrm{c}$ \\
\hline Soil $2\left(500 \mathrm{~g} \mathrm{ZnSO}_{4} .7 \mathrm{H}_{2} \mathrm{O}\right.$ tree $\left.^{-1}\right)$ & 1 & $21.70 c$ & $17.68 \mathrm{~d}$ & $2.30 \mathrm{~b}$ & 3.68 & $5.90 \mathrm{~d}$ & $4.31 \mathrm{c}$ \\
\hline 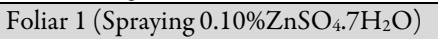 & 2 & $36.38 \mathrm{c}$ & $58.47 \mathrm{c}$ & $3.69 \mathrm{~b}$ & 4.28 & $7.06 \mathrm{~cd}$ & $9.01 \mathrm{~b}$ \\
\hline Foliar 2 (Spraying $0.10 \% \mathrm{ZnSO}_{\left.4.7 \mathrm{H}_{2} \mathrm{O}\right)}$ & 4 & $77.53 \mathrm{~b}$ & $121.60 \mathrm{~b}$ & $3.74 \mathrm{~b}$ & 5.60 & $12.40 \mathrm{~b}$ & $21.94 \mathrm{a}$ \\
\hline 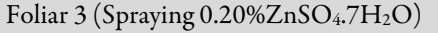 & 2 & $74.07 \mathrm{~b}$ & $97.57 \mathrm{~b}$ & $2.80 \mathrm{~b}$ & 4.47 & $10.41 \mathrm{bc}$ & $10.60 \mathrm{~b}$ \\
\hline 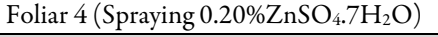 & 4 & $161.78 \mathrm{a}$ & $191.03 a$ & $6.71 \mathrm{a}$ & 5.11 & $18.66 \mathrm{a}$ & $16.74 \mathrm{a}$ \\
\hline $\mathrm{F}$ & & ** & ** & * & NS & ** & ** \\
\hline \multicolumn{2}{|l|}{$\operatorname{LSD}(0.05)$} & 27.31 & 34.35 & 1.81 & & 4.40 & 5.39 \\
\hline $\mathrm{Fe}$ & & \multicolumn{2}{|c|}{ Leaf } & \multicolumn{2}{|c|}{ Fruit Flesh } & \multicolumn{2}{|c|}{ Fruit Peel } \\
\hline $\mathrm{Fe}$ & & Year 1 & Year 2 & Year 1 & Year 2 & Year 1 & Year 2 \\
\hline Control & 0 & $47.33 c$ & $51.88 \mathrm{~d}$ & $3.76 \mathrm{c}$ & 3.98 & $3.59 \mathrm{c}$ & $15.60 \mathrm{bc}$ \\
\hline Soil $1\left(500 \mathrm{~g} \mathrm{FeSO}_{4} .7 \mathrm{H}_{2} \mathrm{O}\right.$ tree $\left.^{-1}\right)$ & 1 & $43.44 \mathrm{c}$ & $49.96 \mathrm{~d}$ & $3.92 \mathrm{c}$ & 2.40 & $2.65 c$ & $11.65 \mathrm{c}$ \\
\hline Soil $2\left(1000 \mathrm{~g} \mathrm{FeSO}_{4 .} .7 \mathrm{H}_{2} \mathrm{O}\right.$ tree $\left.^{-1}\right)$ & 1 & $45.39 \mathrm{c}$ & $57.23 \mathrm{~cd}$ & $6.11 \mathrm{ab}$ & 4.97 & $2.21 \mathrm{c}$ & $11.09 \mathrm{c}$ \\
\hline 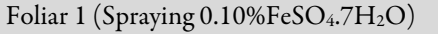 & 2 & $82.23 b c$ & $94.26 c$ & $4.38 \mathrm{bc}$ & 3.62 & $3.00 \mathrm{c}$ & $23.70 \mathrm{ab}$ \\
\hline Foliar 2 (Spraying $0.10 \% \mathrm{FeSO}_{4 .} .7 \mathrm{H}_{2} \mathrm{O}$ ) & 4 & $144.06 \mathrm{~b}$ & $152.40 \mathrm{~b}$ & $4.48 b c$ & 3.68 & $11.61 \mathrm{~b}$ & $32.01 \mathrm{a}$ \\
\hline Foliar 3 (Spraying $0.20 \% \mathrm{FeSO}_{4} .7 \mathrm{H}_{2} \mathrm{O}$ ) & 2 & $131.46 \mathrm{~b}$ & $135.83 \mathrm{~b}$ & $5.25 \mathrm{bc}$ & 4.67 & $6.55 \mathrm{bc}$ & $18.41 \mathrm{bc}$ \\
\hline 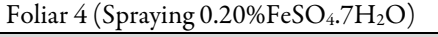 & 4 & $309.89 \mathrm{a}$ & $249.45 \mathrm{a}$ & $7.30 \mathrm{a}$ & 4.40 & $30.22 \mathrm{a}$ & $31.45 \mathrm{a}$ \\
\hline $\mathrm{F}$ & & ** & ** & * & N.S & ** & * \\
\hline $\operatorname{LSD}(0.05)$ & & 67.62 & 39.19 & 2.01 & & 5.29 & 11.65 \\
\hline
\end{tabular}

the fruit samples of the soil-applied treatments clearly exhibited the movement of B from the soil to the fruit. This may be accepted as a proof of translocation of the B treatment to the fruit in pear trees. Either pear is a boron remobilizing plant or boron is phloem mobile in pear and/or pome fruits (Hanson, 1991; Sánchez et al., 1998; Sánchez and Righetti, 2005). As a result, it can be stated that the determination of the leaf $\mathrm{B}$ contents is not a useful tool for estimating the level of $B$ in pear trees. From the current results, it seems justified that the fruit $B$ content is a suitable tool to indicate the B level status of pear trees.

Soil and foliar applications of borax resulted in significant increases in the $\mathrm{B}$ contents in different parts of the trees except for the soil application in experiment IV. Effects of the treatments were more obvious in the first year. This suggests that the regular application of borax is necessary to maintain sufficient B levels in the tree by soil or foliar applications. These results are consistent with the earlier research findings of Sánchez et al. (1998), who showed that soil and foliar applications of boron had effects on the B content in the flower parts in pear. There are also other studies that have reported effects of B compounds on pear trees (Yehia and Hassan, 2005; Jordão et al. 2008; Canesin et al., 2010).

Different combinations of $\mathrm{B}$ with $\mathrm{Zn}$ and $\mathrm{Fe}$ appeared to be effective and increased the leaf and fruit $\mathrm{B}$ concentrations with the application of $\mathrm{B}$ alone. This relationship may be accepted as an example of the synergistic interaction of these nutrients. Similar results were reported by Canesin et al. (2010) who sprayed pears with boric acid and $\mathrm{ZnSO}_{4}$ at $110 \mathrm{~g} \mathrm{ha}^{-1}$ and $250 \mathrm{~g} \mathrm{ha}^{-1}$ concentrations, respectively, in combination with chelating agents. This application caused a significant increase in the leaf $\mathrm{Zn}$ content. However, the final fruit set and the number of fruit were not influenced by the foliar spray with B and $\mathrm{Zn}$.

\section{Conclusions}

The results of this research indicated that the applications of borax (sodium tetra borate decahydrate) via the soil and leaves, increased the B concentrations in all plant parts. Boron in the component plant organs indicated the superiority of the foliar $\mathrm{B}$ application compared with the soil application. As conducted in these experiments, the foliar spraying should be performed 4 times to induce an adequate $\mathrm{B}$ content in the tissues of the pear trees. It was clearly observed that the fruit tissues had more B than did the leaf tissues. Therefore, the fruit $\mathrm{B}$ concentration should be fundamentally considered in evaluation of the $\mathrm{B}$ level status of pear trees. Double and triple combinations of $\mathrm{B}, \mathrm{Zn}$ and Fe in one spray solution could be successfully applied in case of multiple nutrient deficiencies observed in pear trees. These results obviously indicated that the leaf $\mathrm{B}$ concentration is not 
acceptable as a reliable criterion for the determination of the $\mathrm{B}$ level in pear trees. The fruit $\mathrm{B}$ content was found to be a better and more consistent predictor of sufficient $\mathrm{B}$ content in pear trees. Nevertheless, there is a need to have precise preliminary universal critical values for $\mathrm{B}$ in fruit. Thus, the seasonal variations of boron in fruit and a procedure for representative fruit sampling should be determined for a suitable sampling method.

\section{Acknowledgments}

This work was conducted as a part of $\mathrm{PhD}$ Thesis at the Uludağ University, Institute of Natural Sciences, in the guidance of Prof. dr. HalukBAŞAR.

\section{References}

Abdel-Latif E, El Haggan MA (2014). Effect of micronutrients foliar application on yield and quality traids of soybean cultivars. International CropScience 7(11):908-914.

Álvarez-Fernández A, García-Laviña P, Fidalgo C, Abadía J, Abadía A (2004). Foliar fertilization to control iron chlorosis in pear (Pyrus communis L.) trees. Plant and Soil 263:5-15.

Anees M, Tahir FM, Shahzad J, Mahmood N (2011). Effect of foliar application of micronutrients on the quality of mango (Mangifera indica L.) cv.'Dusehri' fruit. Mycopathologia 9(1):25-28.

Anonymous (1995). The land asset of Bursa city. Republic of Turkey. Ministry of Agriculture, Forestry and Rural Affairs, General Directorate of Rural Services, Report No: 16,103 p. Ankara, Turkey.

Asaad SA (2014). The influence of spraying sitofex, iron, manganese and zinc on 'Anna' apple trees planted on new reclaimed calcareous land. Life Science Journal 11:1-8.

Başar H, Katkat AV, Turan MA, Çelik H (2000). Determination of nutritional status of some horticultural crops irrigated with various water resources around Iznik region. Workshop on Environmental Impact of Water Quality, Irrigation Practices Soil Type and Crop Interactions “Abstracts", p 75. November7,2000, Antalya, Turkey.

Başar H (2003). Analytical methods for evaluating iron chlorosis in peach trees. Communications in Soil Science and Plant Analysis 34(3-4):327341.

Bouyoucus GJ (1955). A recalibration of hydrometer method for making mechanical analysis of soils. Agronomy Journal 4:434.

Canesin RCFS, Buzetti S (2007). Leaf spray fertilization of boron and zinc on production, SST and ATT in fruits pear and sugar apple. Revista BrasileiradeFruticultura29(2):377-381.

Canesin RCFS, BuolianiS, Isepon JS (2010). Leaf spray fertilization of boron and zinc on productivity and fruit quality of Japanese pear tree. Acta Horticulturae 872:281-288.

Chapman HD, Pratt F (1961). Methods of analysis for soils, plants and waters. University ofCalifornia, Division of Agricultural Sciences.

EPA (1994). Method EPA 3051, Microwave Assisted Acid Digestion of Sediments, Sludges, Soils and Oils. US Environmental Protection Agency, Office of Solid Waste and Emergency Response. US Government Printing Office, Washington DC 1-14p.

FAO (2014). Food and Agriculture Organization of the United Nations.
Available at: www.faostat3.fao.org[Accessed March 04,2015].

Ferrandon M, Chamel AR (1988). Cuticular retention, foliar absorption and translocation of $\mathrm{Fe}, \mathrm{Mn}$, and $\mathrm{Zn}$ supplied in organic and inorganic form. Journal of Plant Nutrition 11:247-263.

Freeman M, Uriu K, Hartmann HT (2005). Diagnosing and correcting nutrient problems. In: Sibbett GS, Ferguson LF(Eds). Olive production manual. University ofCalifornia, Oakland, California pp 83-100.

Ganie MA, Akhter F, Bhat MA, Malik AR, Junaid JM, Shah MA, Bhat $\mathrm{AH}$, Bhat TA (2013). Boron-a critical nutrient element for plant growth and productivity with reference to temperate fruits. Current Science 104(1):76-85.

Gerçekçioğlu R, Bilginer Ş, Soylu A (2008). Principles of fruit growing. In: Generally Fruit Production. Nobel Press. No: 1280, Ankara, Turkey pp 480.

Hanson E (1991). Movement of Boron out of tree Fruit Leaves. HortScience 26(3):271-273.

Hudina M, Stampar F (2005). The correlation of the pear (Pyrus communis L.) cv. 'Williams' yield quality to the foliar nutrition and water regime. Acta Agriculturae Slovenica 85:179-185.

Jin Z, Minyan W, Lianghuan W, Jiangguo W, Chunhai S (2008). Impacts of combination of foliar iron and boron application on iron biofortification and nutritional quality of rice grain. Journal of Plant Nutrition 31(9):1599-1611.

Jordão PV, Calouro F, Duarte L (2008). Nitrogen and boron fertilization of pear orchards of the Portuguese cultivar 'Rocha'. Acta Horticulturae 800:555-556.

Kacar B, Kovanci I (1982). The chemical phosphorus analysis in plant, soil and fertilizers and assessment of results. Ege University, Faculty of Agriculture Publications. No354, Izmir, Turkey.

KacarB (2009). Soil Analysis. Nobel Press No. 1387, Ankara, Turkey.

Kacar B, Inal A (2008). Plant Analysis. Nobel Press, Ankara, Turkey.

Lindsay WL, Norvell WA (1978). Development of a DTPA soil test for zinc, iron, manganese and copper. Soil Science Society of America Journal 42:421-428.

Marschner H (1995). Mineral Nutrition of Higher Plants. Academic Press, London.

Mirabdulbaghı M (2014). Investigations on determination of nutritional status of pear trees according to a new index-deviation from optimum percentage(DOP). Cercetari Agronomice in Moldova XIVII(4):160.

Nielsen F H (1997). Boron in human and animal nutrition. Plant and Soil 193: 199-208.

Olsen SR, Dean LA (1965). Phosphorus. In: Black CA (Ed). Methods of soil analysis part II. American Society of Agronomy Inc. Madison, Wisconsin pp 1035-1049.

Öztürk A, Oztürk B. (2014). The rootstock influences growth and development of 'Deveci' pear. Turkish Journal of Agricultural and Natural Science 1:1049-1053.

Perica S, Brown PH, Connell JH, Hu H (2002). Olive response to foliar boron application. Acta Horticulturae 586:381-383.

Rodrigues MA, Ferreira IQ, Claro AM, Arrobas M (2012). Fertilizer recommendations for olive based upon nutrients removed in crop and pruning. Scientia Horticulturae 142:205-211.

SajidM, RabA, Ali N, ArifM, Ferguson L, Ahmed M(2010).Effect of foliar 
132 application of $Z n$ and $B$ on fruit production and physiological disorders in sweet orange cr. Blood orange. Sarhad Journal of Agriculture 26(3):355-360.

Sánchez EE, Righetri TL (2005). Effect of postharvest soil and foliar application of boron fertilizer on the partitioning of boron in apple trees. HortScience 40(7):2115-2117.

Sánchez EE, Righetti TL, Sugar D (1998). Partitioning and recycling of fall applied boron in Comice pears. Acta Horticulturae 475:347-354

SAS (2005). Jump 6.0 Statistical Discovery From SAS. SAS Institute Inc. SAS Campus Drive, Cary, NC, 27513, USA. Available at: http//www.jmpin.com (Accessed29 April 2011)

Shoeib MM, El Sayyed A (2003). Response of Thompson seedless grape vines to the spray of some nutrients and citric acid. Minia Journal of Agricultural Research and Development 23(4):681-698.

Shorrocks VM (1997). The occurrence and correction of boron deficiency. Plant and Soil 193:121-148.

Stellacci AM, Caliandro A, Mastro MA, Guarini D (2010). Effect of foliar boron application on olive (Olea europaea $\mathrm{L}$ ) fruit set and yield. Acta Horticulturae 868:267-272.

Tagiliavini M, Rombolá $\mathrm{AD}$ (2001). Iron deficiency and chlorosis in orchard and vineyard ecosystems. European Journal of Agronomy 15:71-92.

Taheri M, Talai A (2001). The effects of chemical sprays on the qualitative and quantitative characteristics of 'Zard' olive fruits. Proc. IV IS on Mineral Nutrition in Fruit. Acta Horticulturae 564:343-348.

TUIK (2013). Turkish Statistical Institute. Available at: http://www.turkstat.gov.tr (Accessed March 04, 2015).

Turan HS, Aydogdu E, Pekcan T, Çolakoglu H (2013). Microelement status and soil and plant relationships of olive groves in west Anatolia region of Turkey. Communications in Soil Science and Plant Analysis 44:80-88.
USDA (2013). US Dept of Agriculture soil taxonomy. Available at: http://soils.usda.gov/technical/classification/osd/index.html (Accessed Dec 13, 2013).

Walkley A, Black LA (1934). An examination of the Degtjareff method for determining soils organic matter and a proposed modification of the chromic acid titration method. Soil Science 37:29-38.

Wallinga I, van Vark W, Houba VJG, van der Lee JJ (1989). Plant Analysis Procedures (Soil an Plant Analysis, Part 7). Wageningen Agricultural University, Dept. of Soil Science and Plant Nutrition. The Netherlands.

Wolf B (1971). The determination of boron in soil extracts, plant materials, manures, waters and nutrient solution. Soil Science and Plant Nutrition 2(5):363-374.

Wojcik P (2004). Uptake of mineral nutrients from foliar fertilization. Journal of Fruit and Ornamental Plant Research 12:201-218.

Wojcik P, Wojcik M (2003). Effects of boron fertilization on Conference pear tree vigor, nutrition, and fruit yield and storability. Plant and Soil 256:413-421.

Velioğlu S, Şimşek A (2003). Effects of boron in human health and nutrition (Abstract in English). Anadolu University Journal of Science and Technology 4(2): 123-130.

Yadav V, Singh PN, Yadav P (2013). Effect of fertilization of boron, zinc and iron on fruit growth and yield of low-chill peach cv. Sharbati. International Journal of Scientific and Research Publications 3(8):1-6.

Yehia TA, Hassan HSA (2005). Effect of some chemical treatments on fruiting of Leconte pears. Journal of Applied Sciences Research 1(1):3542.

Zhang Q, Brown PH (1999). Distribution and transport of foliar applied zinc in pistachio. Journal of the American Society for Horticultural Science 124(4):433-436. 